\title{
64. The Effect of Aclacinon on the Repair of the Sublethal and the Potentially Lethal $X$-Ray Damages in HeLa Cells
}

\author{
By Kihei Kubo, Soichiro KoIwaI, and Kazuo Morita \\ Department of Radiology, Sapporo Medical College, Sapporo 060
}

(Communicated by Sajiro Makıno, M. J. A., Sept. 12, 1986)

Aclacinon (ACR: aclacinomycin A), an antitumor drug of the anthracyclines, has been known as the potent inhibitor of the RNA synthesis (Oki et al. 1975; Oki 1977; Crooke et al. 1978; Koiwai et al. 1985). Recently, the drug has been shown to potentiate the X-ray-induced killing of the mammalian cells in culture (Miyamoto et al. 1983; Kubo et al. 1985). In the present article is to be reported the effect of ACR on the repair of the X-ray damages in HeLa cells.

Materials and methods. A radioresistant strain (RC-355) of the HeLa cells was grown as a monolayer in Eagle's minimum essential medium (MEM), supplemented with $10 \%$ fetal bovine serum at $37^{\circ} \mathrm{C}$ in a humidified air containing $5 \% \quad \mathrm{CO}_{2}$ (Kubo et al. 1982). ACR was kindly provided by the Yamanouchi Seiyaku Co., Tokyo, Japan. The drug was dissolved in the phosphate buffered saline at $1 \mathrm{mg} / \mathrm{ml}$, sterilized and kept frozen at $-21^{\circ} \mathrm{C}$. Just before the use, the thawed solution was diluted with the medium and applied. The concentration was determined by the measurement of the optical absorbance.

In order to determine the effect of the ACR on the X-ray response of RC-355 cells, an appropriate number of the cells were plated onto the plastic Petri dishes (Falcon 3002). The cells were incubated for the attachment for about $3 \mathrm{hr}$ after plating. When the cells were treated in the plateau-phase, the cells were plated onto the plastic dishes (Falcon 3001), grown to be confluent, and incubated 3 more days in the serum-free medium. The dishes were $\mathrm{X}$-irradiated on a rotating platform at the room temperature. The X-irradiation was carried out with a Siemens Stabilipan X-ray source operating at $300 \mathrm{kVp}$ and $12 \mathrm{~mA}$ with $0.5 \mathrm{~mm}$ filters. ACR was added to the dishes just after the irradiation and removed by rinsing the dishes with the prewarmed medium. The fresh medium was then added for the colony formation. In the case of the experiments with plateauphase cells, the confluent monolayers were trypsinized and the appropriate number of cells were inoculated for the colony-assay immediately or $24 \mathrm{hr}$ after the irradiation (Kubo et al. 1986).

The cell survival was determined by the colony-forming method and only the colonies containing more than 50 cells were counted as viable.

Results and remarks. Fig. 1a shows the result of an experiment in which the ability of the RC-355 cells to repair the sublethal X-ray damages (SLDR) was tested. When the dose was delivered in two fractions, the second irradiation was carried out at the different incubation periods following the first dose of $4 \mathrm{~Gy}$. The greater extent of SLDR was observed for the longer repair interval.

In Fig. 1b, the effect of ACR on SLDR is depicted. When the cells were treated with ACR during the interval between the two fractionated X-ray doses, both the post-treatment effect for the first dose and the pre-treatment effect for 


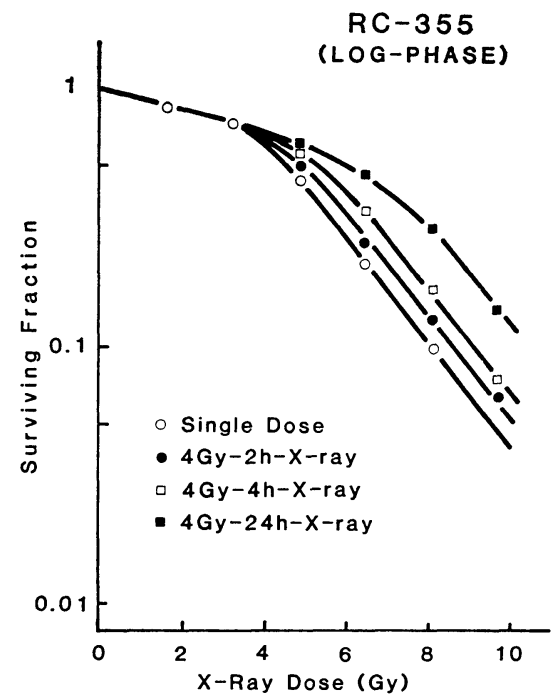

Fig. 1a

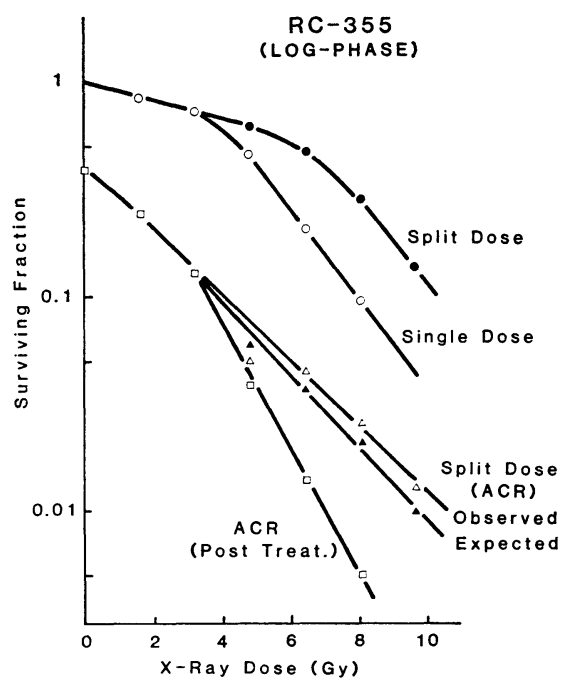

Fig. 1b

Fig. 1. a: The repair of the sublethal X-ray damage in radioresistant HeLa RC355 cells. The cells were exposed to various doses of X-rays 2 to $24 \mathrm{hr}$ after the first dose $(4 \mathrm{~Gy})$. $\mathrm{b}$ : The effect of ACR on the repair of the sublethal damage. The cells were treated with $0.1 \mu \mathrm{g} / \mathrm{ml} \mathrm{ACR}$ during the repair interval (24 hr) between the two fractionated X-ray doses.

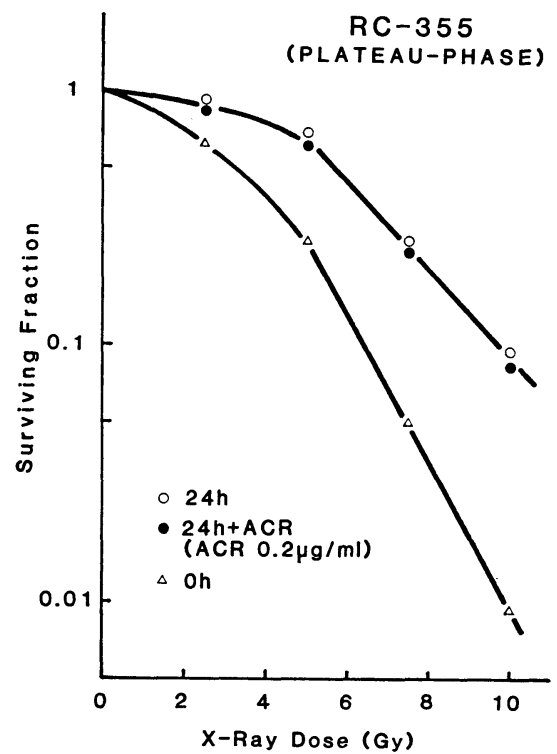

Fig. 2a

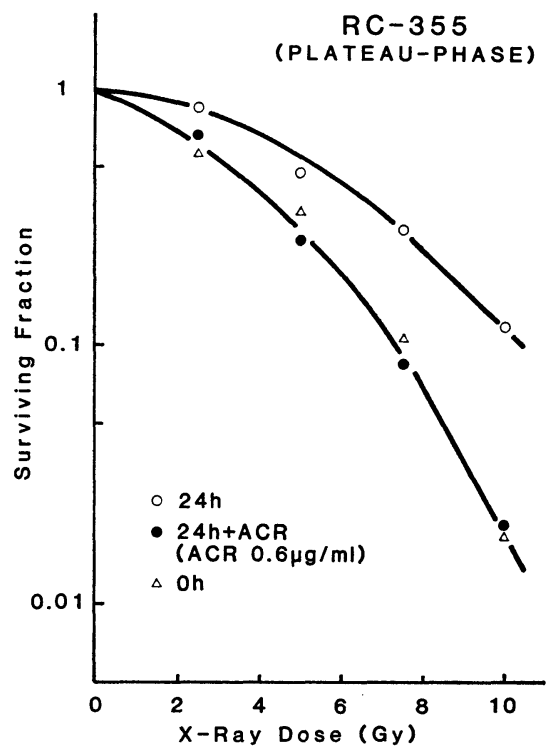

Fig. $2 b$

Fig. 2. The effect of ACR on the repair of the potentially lethal X-ray damages in the plateau-phase RC-355 cells. The cells were replated immediately $(0 \mathrm{~h})$ or 24 hours $(24 \mathrm{~h})$ after $\mathrm{X}$-irradiation for the colony-forming assay. The treatment with ACR was carried out during the repair period of $24 \mathrm{hr}$ at 0.2 (Fig. 2a) and 0.6 (Fig. 2b) $\mu \mathrm{g} / \mathrm{ml}$. 


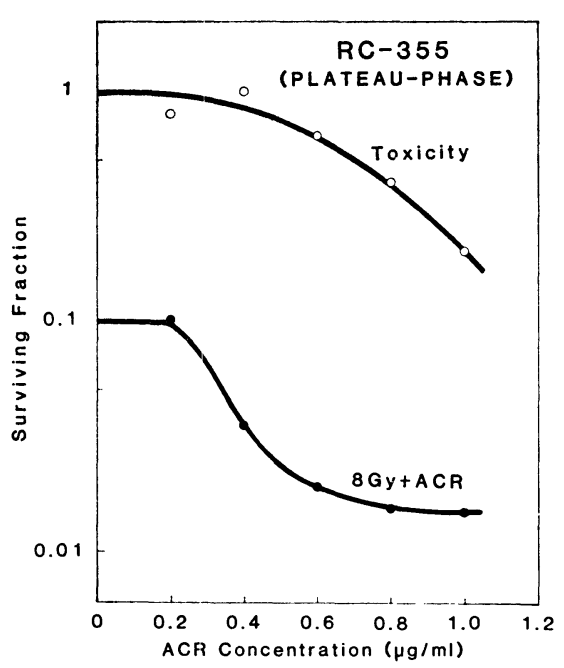

Fig. 3. The effect of ACR on the X-irradiated RC-355 cells in the plateau-phase. The cells were irradiated with 8 Gy and then treated with ACR at the concentrations indicated. Following the incubation period (24 hr) with ACR, the cells were replated for the colony formation.

the second irradiation should be observed. As shown in the figure (Fig. 1b), the observed survival value was quite similar to the expected value which was calculated on the assumptions that the pre- and post-irradiation effect by the drug has been taken place independently and any sublethal damages were not repaired during the interval. It seems possible to conclude that ACR inhibits SLDR at the relatively the low concentration.

The effect of ACR on the repair of potentially lethal X-ray damages (PLDR) was studied using the plateau-phase RC-355 cells. The increase in survival was observed as the result of PLDR when the trypsinization and the plating for the colony-formation was delayed $24 \mathrm{hr}$ after the irradiation (Fig. 2). ACR seems to inhibit the repair completely at the concentration of $0.6 \mu \mathrm{g} / \mathrm{ml}$ (Fig. 2b), although at $0.2 \mu \mathrm{g} / \mathrm{ml}$ no effect of the drug was observed (Fig. 2a). As shown in Fig. 3, the toxicity of the drug for the plateau-phase cells was not apparent at the concentrations less than $0.4 \mu \mathrm{g} / \mathrm{ml}$. On the other hand, the post-treatment effect of ACR was appreciable at $0.4 \mu \mathrm{g} / \mathrm{ml}$. It is, therefore, reasonable to conclude that ACR potentiate the X-ray-induced killing of the plateau-phase HeLa cells by inhibiting the PLDR. It also should be noted that a relatively high concentration $(0.6 \mu \mathrm{g} / \mathrm{ml})$ was necessary for the complete inhibition of the repair and that the other explanation for the potentiating effect might be also possible because of the toxicity (Kubo et al. 1985).

Acknowledgements. The authors are deeply indepted to Emeritus Professor Sajiro Makino, M. J. A., for his critical reading. The work was supported by a Grant-in Aid for Cancer Research (57010008) from the Ministry of Education, Science and Culture, Japan. 


\section{References}

Crooke, S. T. et al. (1978) : Molecular Pharmacol., 31, 1149-1154.

Koiwai, S., Kubo, K., and Morita, K. (1985) : Proc. Japan Acad., 61B, 219-222.

Kubo, K., Koiwai, S., and Morita, K. (1982) : J. Radiat. Res., 23, 204-217.

- (1985) : Proc. Japan Acad., 61B, 322-324.

Miyamoto, T., Wakabayashi, M., and Terasima, T. (1983) : Radiology, 149, 835-839.

Oki, T. (1977) : Jap. J. Antibiot., 30, suppl., 70-84.

Oki, T. et al. (1975) : J. Antibiot., 28, 830-834. 